\title{
ОБҐРУНТУВАННЯ УПРАВЛІСЬКИХ РІШЕНЬ ПРИ ВИБОРІ ІНВЕСТИЦІЙНИХ ПРОЄКТІВ, ФІНАНСОВИЙ АСПЕКТ
}

Розкрито суть та значення обґрунтування інвестицій у великі соціально-екологічні проєкти та проблеми оцінки ефективності таких проєктів. Різні інвестиційні проєкти, що фінансуються за рахунок коштів бюджету всіх рівнів підлягають державній експертизі, що здійснюється уповноваженими на те органами державної влади. Інвестиційні проєкти незалежно від джерел фінансування і форм власності об'єктів капітальних вкладень підлягають експертизі до їх затвердження, зокрема екологічній експертизі. Рішення щодо оцінки інвестиційного проєкту полягає у визначенні різних видів ефективності інвестиційного проєкту: суспільної, комерційної ефективності участі в проєкті. Ефективність участі в проєкті включає: ефективність для підприємствучасників, ефективність для акціонерів підприємств-учасників, бюджетну ефективність. При цьому, під «ефективністю» мається на увазі те, наскільки реалізація даного проєкту відповідає меті і інтересам його учасників, а також тих, кого безпосередньо стосується процес реалізації.

Отож, необхідно підібрати критерії оцінки інвестиційних проєктів, які будуть основою для прийняття управлінських рішень. Обґрунтування економічної ефективності інвестиційного проєкту характеризується системою показників, що відображають співвідношення витрат і фінансових результатів реалізації проєкту. Витрати і інші результати проєкту в розрахунках економічної ефективності виражаються у вигляді грошового потоку. Проаналізовано основні методи оцінки інвестиційних проєктів їх суть, переваги і недоліки. Для визначення ціни ризику рекомендується використовувати показники, які враховують як можливість настання несприятливої події, так і величину збитку від нього. Такими показниками можуть бути дисперсія, середньоквадратичне відхилення і коефіцієнт варіації. Для можливості економічного тлумачення i порівняльного аналізу цих показників рекомендується переводити їх в грошовий формат. Запропоновано комплекс показників для оцінки інвестиційних проєктів 3 мінімізацією ризиків.

Ключові слова: методи; управлінські рішення; інвестиційні проєкти; ефективність; інфляційний ризик; витрати; грошовий потік; експертиза; 
соціально-екологічний проєкт; рентабельність; фінансовий менеджмент.

Постановка проблеми. Інвестиційні проєкти незалежно від джерел фінансування і форм власності об'єктів капітальних вкладень підлягають експертизі до їх затвердження.

Експертиза інвестиційних проєктів проводиться в цілях запобігання створенню об'єктів, використання яких порушує права фізичних і юридичних осіб і інтереси держави або не відповідає вимогам затверджених в установленому порядку стандартів (норм i правил), а також для оцінки ефективності здійснюваних капітальних вкладень.

Різні інвестиційні проєкти, що фінансуються за рахунок коштів бюджету всіх рівнів підлягають державній експертизі, що здійснюється уповноваженими на те органами державної влади. Всі інвестиційні проєкти підлягають екологічній експертизі. Отож, необхідно підібрати критерії оцінки інвестиційних проєктів, які будуть основою для прийняття управлінських рішень.

Аналіз останніх досліджень і публікацій. Значний вклад у розвиток теоретичних підходів до розробки методики оцінки інвестицій та інвестиційних проєктів здійснили вітчизняні та зарубіжні вчені, такі як Бланк Й. А., Габович Б. А., Данг А. З., Мищенко А. В., Голуб Л. Г., Хямаленс В. О., Крупка Я. Д., Литвин Б. М., Савчук В. П., Прилипко С. И., Величко Е. Г., Холт Р., Федоренко В. Г. та багато інших. Частина досліджень дозволяє судити про поріг рентабельності і запас фінансової міцності проєктів. Використання досліджень методів оцінки інвестицій ускладнюється трудністю прогнозування ставки дисконтування (середньої вартості капіталу) i ставки банківського відсотка на тривалі періоди.

Мета статті (постановка завдання). Обґрунтувати відбір методів та показників для оцінки проєктів зокрема соціально-екологічного спрямування.

Отож, необхідні проаналізувати та запропонувати обґрунтування використання певних методів при прийнятті управлінських рішень щодо доцільності реалізації складних інвестиційних проєктів.

\section{Виклад основного матеріалу}

Прийняття управлінського рішення при оцінці ефективності інвестиційних проєктів доцільно здійснювати на основі єдиних принципів, таких як:

- розгляд проєктів з точки зору тривалості всього життєвого 
циклу (розрахункового періоду) - від проведення передінвестиційних досліджень до припинення проєкту;

- розробки моделювання грошових потоків, що включають всі пов'язані із здійсненням проєкту грошові надходження і витрати за розрахунковий період з урахуванням можливості використовування різних валют;

- уніфіковані (однакові) критерії порівняння різних проєктів та їх варіантів;

- позитивність або максимум ефекту;

- тривалість реалізації проєкту;

- витрат і надходжень порівняльний аналіз, при реалізації проєкту включаючи витрати, пов'язані із залученням раніше створених виробничих фондів, а також майбутніх втрат, безпосередньо викликаних здійсненням проєкту; раніше створені ресурси, що використовуються в проєкті, оцінюють не витратами на їх створіння, а альтернативною вартістю, що відображає максимальне значення упущеної вигоди;

- прогнозування та облік всіх найістотніших результатів (наслідків) проєкту;

- можливість поетапної оцінки;

- наявність важелів впливу на ефективність реалізації інвестиційного проєкту і потреби в оборотному капіталі;

- прогнозні показники інфляції та їх облік на етапах реалізації проєкту;

- інші ризики та рівень невизначеності та можливості врахування при супроводженні реалізації проєкту.

Прийняття управлінського рішення передбачає обов'язкову наявність головної мети проєкту та його обґрунтування: відшкодування вкладених засобів за рахунок доходів від реалізації проєкту; приріст капіталу, мінімальний рівень прибутковості, що компенсує загальну (інфляційну) зміну купівельної спроможності грошей, а також покриваючий ризик інвестора, пов'язаний із здійсненням проєкту; окупність інвестицій в межах встановленого терміну.

Інвестиційні проєкти незалежно від джерел фінансування і форм власності об'єктів капітальних вкладень підлягають експертизі до їх затвердження.

Вищезгадана експертиза інвестиційних проєктів проводиться в цілях запобігання створенню об'єктів, використання яких порушує права фізичних і юридичних осіб і інтереси держави або не 
відповідає вимогам затверджених в установленому порядку стандартів (норм і правил), а також для оцінки ефективності здійснюваних капітальних вкладень.

Різні інвестиційні проєкти, що фінансуються за рахунок коштів бюджету всіх рівнів підлягають державній експертизі, що здійснюється уповноваженими на те органами державної влади. Всі інвестиційні проєкти підлягають екологічній експертизі.

Рішення щодо оцінки інвестиційного проєкту полягає у визначенні різних видів ефективності інвестиційного проєкту: суспільної, комерційної ефективності участі в проєкті. Ефективність участі в проєкті, у свою чергу, включає: ефективність для підприємств-учасників, ефективність для акціонерів підприємствучасників, бюджетну ефективність. При цьому, під «ефективністю» мається на увазі те, наскільки реалізація цього проєкту відповідає меті і інтересам його учасників, а також тих, кого безпосередньо стосується процес реалізації.

Оцінки інвестиційного проєкту для подальшого прийняття рішення потрібне для:

- визначення ефективності і можливості фінансової реалізації інвестиційного проєкту;

- визначення ефективності учасників інвестиційного проєкту, окремих господарюючих суб'єктів;

- підготовки висновків за економічними розділами при проведенні державної, галузевий і інших видів експертиз обґрунтовувань інвестицій, ТЕО, проєктів і бізнес-планів;

- порівняння альтернативних інвестиційних проєктів і оцінки економічних наслідків вибору одного з них;

- для оцінки економічних наслідків відбору для реалізації групи інвестиційних проєктів з деякої їх сукупності за наявності фіксованих фінансових і інших обмежень;

- ухвалення рішень про державну підтримку інвестиційних проєктів;

- ухвалення економічно обґрунтованих вдосконалень (рішень) про зміни в ході реалізації інвестиційних проєктів залежно від зміни обставин.

Розробка управлінських рішень передбачає використання багатьох методів прийняття рішень. Зокрема, методи аналізу інвестиційних проєктів їх суть, доцільність використання та переваги і недоліки.

Отже, розглянем та проаналізуємо декілька з них. 
Метод простої (бухгалтерської) норми прибутку. Цей метод базується на розрахунку відношення середньої за період життя проєкту чистого бухгалтерського прибутку і середньої величини інвестицій (витрати основних і оборотних засобів) в проєкт. Вибирається проєкт 3 найбільшою середньою бухгалтерською нормою прибутку. Основною перевагою даного методу $\epsilon$ його простота для розуміння, доступність інформації, нескладність обчислення. Недоліком його $є$ те, що він не враховує деяких видів витрат (типу амортизації) і пов'язану з цим податкову економію, можливості реінвестування одержаних доходів, часу притоку i відтоку грошових коштів і тимчасову вартість грошей.

Метод розрахунку періоду окупності проєкту. Обчислюється кількість років, необхідних для повного відшкодування первинних витрат, тобто визначається момент, коли грошовий потік доходів порівняється з сумою грошових потоків витрат. Відбирається проєкт 3 мінімальним терміном окупності. Метод не враховує можливості реінвестування доходів і тимчасовість певної вартості грошей.

Дисконтний метод окупності проєкту визначає термін, через який дисконтні грошові потоки доходів порівняються з дисконтними грошовими потоками витрат. При цьому використовується концепція грошових потоків, враховується можливість реінвестування доходів і тимчасова вартість грошей на відповідний період.

Обидва методи чи модифікації даного методу прості в розумінні і застосуванні і дозволяють судити про ліквідність і ризик проєкту, оскільки тривала окупність означає тривалу іммобілізацію засобів (знижену ліквідність проєкту) і підвищений ризик проєкту. Проте обидві модифікації ігнорують грошові надходження після закінчення терміну окупності проєкту. Вони успішно застосовуються для швидкої оцінки проєктів, а також в умовах значної інфляції, політичної нестабільності або при дефіциті ліквідних засобів - тобто в обставинах, орієнтуючих підприємство на отримання максимальних доходів в найкоротші терміни.

Метод чистої справжньої (поточної) вартості. Чиста справжня вартість проєкту визначається як різниця між сумою справжніх вартостей всіх грошових потоків доходів і сумою справжніх вартостей всіх грошових потоків витрат, тобто як чистий грошовий потік від проєкту, приведений до справжньої вартості. Коефіцієнт дисконтування при цьому приймається рівним середній вартості капіталу. Проєкт схвалюється, якщо чиста справжня вартість проєкту більше нуля. 
Даний метод не дозволяє судити про поріг рентабельності і запас фінансової міцності проєкту. Використання даного методу ускладнюється трудністю прогнозування ставки дисконтування (середньої вартості капіталу) і ставки банківського відсотка.

При розгляді єдиного проєкту або виборі між незалежними проєктами застосовується метод, внутрішньої ставки рентабельності. При виборі між альтернативними проєктами він застосовується як метод, що відповідає основній задачі фінансового менеджменту примноження доходів власників підприємства.

Метод внутрішньої норми рентабельності. Всі надходження i витрати за проєктом призводять до справжньої вартості за ставкою дисконтування, отриманій не на середній вартості капіталу, що задається ззовні, а на основі внутрішньої ставки рентабельності самого проєкту, яка визначається як ставка прибутковості, при якій справжня вартість надходжень рівна справжній вартості витрат, тобто чиста справжня вартість проєкту рівна нулю.

Визначена таким чином чиста справжня вартість проєкту порівнюється $з$ чистою справжньою вартістю витрат. Схвалюються проєкти з внутрішньою нормою рентабельності, що перевищує середню вартість капіталу (що приймається за мінімально допустимий рівень прибутковості). Даний метод припускає складні обчислення і не завжди виділяє найприбутковіший проєкт. Метод припускає ситуацію реінвестування всіх проміжних грошових надходжень від проєкту за ставкою внутрішньої прибутковості. Проте метод враховує зміни вартості грошей в часі.

Запропоновані на розгляд методи аналізу інвестиційних проєктів дає можливість уточнити окремі характеристики і особливості проєкту. Найефективнішим способом оцінки і вибору інвестиційних проєктів потрібно визнати комплексне застосування всіх основних методів при аналізі кожного проєкту.

Визначати ефективність інвестиційного проєкту щодо окупності за рахунок доходів, пропонується здійснювати за нижчеописаною методикою.

Інвестиції або капітальні вкладення оцінюються в діючих (на дату складання інвестиційного проєкту) цінах 3 урахуванням коефіцієнта (дефлятора) на основі внутрішніх будівельних титульних списків і проєктно-кошторисної документації. При цьому капітальні вкладення минулого і майбутніх періодів за реалізації інвестиційного проєкту в розрахунки не враховуються.

Порівняльний розрахунок проводиться тільки для проєктів, введення яких в експлуатацію відбудеться в плановому році. Якщо в 
будь-яких проєктах для отримання запланованого доходу потрібні додаткові інвестиції, або роботи наступного періоду, то в таких проєктах враховуються тільки витрати планового року без врахування доходу.

Величина експлуатаційних витрат визначається на основі аналізу фактичної калькуляції витрат на виробництво з виділенням умовно-постійних і умовно-змінних витрат. В розрахунках економічної ефективності інвестиційного проєкту враховуються експлуатаційні витрати тільки по новостворених або придбаних активах.

У першому році інвестиційного проєкту інвестиції враховують на початку кожного кварталу в об'ємі, відповідно до плану капітального будівництва; виручка, експлуатаційні витрати, податки враховуються на початку того кварталу, в якому вони виникають;

Для другого і подальших років відповідні річні об'єми доходів і витрат враховуються одноразово в середині кожного періоду.

При розробці інвестиційного проєкту формуються умови відповідних сценаріїв, які відображають значення наступних показників: величина інфляції; валютний курс; ціни на енергоносії і нафтопродукти на зовнішньому і внутрішньому ринках; ціни на газ; акциз на нафту; комерційні витрати на реалізацію нафти і нафтопродуктів; витрати на виробництво нафтопродуктів; мінімальна не ризикова ставка прибутковості; ставка (норма) дисконту; прогноз зміни податків.

Можливі сценарії і відповідні умови формуються не менше, ніж для двох варіантів розрахунку: в «постійних цінах» середніх на планований рік; в «поточних цінах».

Метод розрахунку «в постійних цінах» припускає використовування фіксованих на весь період розрахунку значень цін на продукцію, послуги, устаткування, матеріали і т.п. Розрахунок «в поточних цінах» проводиться 3 урахуванням зміни цін протягом періоду розрахунку, тобто розрахунок кожного періоду - місяця, кварталу, року - проводиться в цінах саме цього (поточного) кроку періодичності.

Обґрунтування економічної ефективності інвестиційного проєкту характеризується системою показників, що відображають співвідношення витрат і фінансових результатів реалізації проєкту. Витрати й інші результати проєкту в розрахунках економічної ефективності виражаються у вигляді грошового потоку CF (cash flow), який розраховується за формулою

$$
C F_{i}=4 \Pi_{i}+A O_{i}-1
$$


де ЧП

$\mathrm{AO}_{\mathrm{i}}$ - амортизаційні відрахування в і-му році від нових активів (що вводяться за рахунок інвестицій);

I - інвестиції в планованому році.

Оцінка економічної ефективності інвестицій, грошових потоків, що утворюються в різні моменти часу, приводять (дисконтують) до планованого року. В розрахунках приймається, що в планованому році проводяться всі інвестиції і цей рік $€$ першим кроком розрахунку. Тому дисконтування грошового потоку планового року не проводиться. Ставка (норма) річного дисконту розраховується за формулою:

$$
\mathrm{D}=((1+\mathrm{R}) *(1+\mathrm{I}) *(1+\mathrm{B})-1) * 100,
$$

де $\mathrm{R}$ - мінімальна неризикова норма прибутковості в рік, частки од.;

I - середньорічний темп інфляції протягом періоду розрахунку проєкту, частки од. (для розрахунку ТЕП в «постійних цінах» I = 0);

В - додаткове страхування від ризиків (технічних, політичних, фінансових), частки од. (при розрахунку без урахування специфічного ризику проєкту $\mathrm{B}=0$ ).

При визначення економічної ефективності інвестицій використовують наступну систему показників.

Перший з них чистий дисконтний (приведений) потік NPV (Net present value) - сума дисконтних річних грошових потоків (CF) за весь періоду реалізації проєкту:

$$
\mathrm{NPV}=\sum_{\mathrm{i}=1}^{\mathrm{i}=N}\left(\text { ЧП }+\mathrm{AO}_{1}-\text { И) } /(1+\mathrm{D})^{\mathrm{i}-1} .\right.
$$

де D - ставка (норма) дисконту \%;

$\mathrm{N}$ - період розрахунку, літ;

і - порядковий номер року.

По-друге дисконтний термін окупності інвестицій DPB (Discounted payback period), який виражається в одиницях часу і $€$ кількісною оцінкою проміжку часу, протягом якого відбувається повне відшкодування інвестицій. Тобто часу від початку реалізації інвестиційного проєкту до моменту, коли дисконтна сума надходжень грошових коштів від реалізації інвестиційного проєкту досягає величини інвестицій (тобто до моменту, коли наростаючий NPV досягає нульового значення):

$$
\mathrm{NPV}=\sum_{\mathrm{i}=1}^{\mathrm{i}=\mathrm{DPB}_{\mathrm{i}}}\left(\mathrm{Ч}_{\mathrm{i}}-\mathrm{AO}_{\mathrm{i}}-\text { И }\right) /(1+\mathrm{D})^{\mathrm{i}-1}=0 \text {. }
$$

Ще один важливий показник індекс прибутковості (прибутковості) PI (Profitability index), який є відносною величиною і показує в скільки разів сумарні дисконтні доходи в результаті 138 
реалізації інвестиційного проєкту перевищують інвестиції планованого року:

$$
\mathrm{PI}=\frac{\sum_{\mathrm{i}=1}^{\mathrm{i}=\mathrm{N}}\left(\mathrm{U} \Pi_{\mathrm{i}}+\mathrm{AO}_{\mathrm{i}}\right) /(1+\mathrm{D})^{\mathrm{i}-1}}{И} .
$$

I внутрішня норма рентабельності IRR (Internal rate return), яка вимірюється у відсотках і відображає середньорічну прибутковість на вкладений капітал. Для проєктів пов'язаних із створенням нових виробничих потужностей підприємства за рахунок його власних засобів, внутрішня норма рентабельності розраховується шляхом визначення такого значення ставки дисконтування, при якому чистий приведений потік за весь період розрахунку ІП приймає нульове значення:

$$
\mathrm{NPV}=\sum_{\mathrm{i}=1}^{\mathrm{i}=N}\left(\mathrm{Ч \Pi}_{\mathrm{i}}+\mathrm{AO}_{\mathrm{i}}-\text { И) } /(1+\mathrm{IRR})^{\mathrm{i}-1}=0 \cdot\right.
$$

Отож, інвестиційний проєкт вважають ефективним, якщо його прибутковість і ризик збалансовані в прийнятній для інвесторів пропорції. Під «прибутковістю» розуміють співвідношення результатів і витрат.

Ризик - рівень фінансових втрат, що виражається: в можливості не досягт поставленої мети; в невизначеності прогнозованого результату; в суб'єктивності оцінки прогнозованого результату.

Перший підхід: ризик оцінюють як суму можливих втрат, зважених за їх вірогідністю.

Другий підхід: ризик оцінюють як суму ризиків від ухваленого рішення і ризиків зовнішнього характеру (незалежних від ухваленого рішення).

Третій підхід: ризик визначають як добуток вірогідності настання негативної події на ступінь негативних наслідків.

Також існує узагальнений комплексний критерій - «ціна ризику» (3 risk), який характеризує величину умовних втрат, можливих при реалізації інвестиційного рішення:

$$
\boldsymbol{3}_{\text {risk }}=\{\boldsymbol{P} ; \boldsymbol{L}\} \text {, }
$$

де $\boldsymbol{L}$ - визначають як суму можливих прямих втрат від інвестиційного рішення.

Для визначення ціни ризику рекомендується використовувати показники, які враховують як можливість настання несприятливої події, так і величину збитку від нього. Такими показниками можуть бути дисперсія, середньоквадратичне відхилення і коефіцієнт 
Серія «Економічні науки»

Випуск 3(95) 2021 р.

варіації. Для можливості економічного тлумачення і порівняльного аналізу цих показників рекомендується переводити їх в грошовий формат.

Розрахункові криві корисності, будучи виразом індивідуальних вимог інвестора, дозволяють ухвалювати інвестиційні рішення 3 урахуванням його переваг.

Прийняття рішення про ефективність інвестиційного проєкту в умовах невизначеності, інвестор бере до уваги як мінімум задачу за двома критеріями, інакше кажучи, йому необхідно знайти оптимальне поєднання ризику і прибутковості. Зазвичай складно знайти ідеальний варіант «максимальна прибутковість мінімальний ризик» і вдається це лише в окремих випадках. I тому можна використовувати чотири способи для вирішення цієї оптимізаційної задачі.

1. Спосіб «максимум виграшу» полягає в тому, що зі всіх варіантів вкладень капіталу вибирається варіант, що дає найбільший результат (NPV, прибуток) при прийнятному для інвестора ризику ( $R$ пр.доп). Таким чином, критерій ухвалення рішення у формалізованому вигляді можна записати як

$$
\begin{aligned}
& \boldsymbol{N P V} \rightarrow \max \\
& \boldsymbol{R}_{u n}=\boldsymbol{R}_{n p . \partial o n}
\end{aligned}
$$

2. Другий спосіб «оптимальна вірогідність» полягає в тому, що 3 можливих рішень вибирається те, при якому вірогідність результату $\epsilon$ прийнятною для інвестора.

3. Більш практичний спосіб «оптимальна вірогідність» рекомендується поєднувати 3 підходом «оптимальне коливання». Коливання показників виражається їх дисперсією, середнім квадратичним відхиленням і коефіцієнтом варіації. Стратегія оптимального коливання результату полягає в тому, що з можливих рішень вибирається те, при якому вірогідність виграшу і програшу для одного і того ж ризикового вкладення капіталу має невеликий розрив, тобто якнайменшу величину дисперсії, середнього квадратичного відхилення, варіації.

$$
\boldsymbol{C V}(\boldsymbol{N P V}) \rightarrow \min ,
$$

де $\boldsymbol{C V}(\boldsymbol{N P V})$ - коефіцієнт варіації NPV.

4. Спосіб «мінімум ризику». Тобто з всіх можливих варіантів вибирається той, який дозволяє отримати очікуваний виграш (NPV пр.доп) при мінімальному ризику.

$$
\begin{aligned}
& \boldsymbol{N P V}=\boldsymbol{N P V}{ }_{n p . \partial o n} . \\
& \boldsymbol{R}_{u n} \rightarrow \min
\end{aligned}
$$

При прийнятті управлінського рішення беруть до уваги 
фінансові ризики обумовлені вірогідністю втрат внаслідок здійснення фінансової діяльності в умовах невизначеності. До фінансових ризиків відносять:

- ризики коливань купівельної спроможності грошей (інфляційний, дефляційний, валютний);

- інфляційний ризик інвестиційного проєкту обумовлений, перш за все, непередбачуваністю інфляції; помилковий темп інфляції, закладений в ставку дисконтування, може істотно спотворити значення показника ефективності, не говорячи вже про те, що умови функціонування суб'єктів господарювання істотно розрізняються при різному темпі інфляції.

Отож, небезпека інфляції полягає не стільки в їі величині, скільки в іï непередбачуваності. За умови передбаченості i визначеності навіть найбільшу інфляцію можна легко врахувати в інвестиційному проєкті або в ставці дисконтування, або індексуючи величину грошових потоків, звівши тим самим елемент невизначеності, а значить і ризик, до нуля.

Валютний ризик - ризик втрат фінансових ресурсів внаслідок непередбачуваних коливань валютних курсів. Найтвердішій валюті властива внутрішня інфляція, а динаміка їі купівельної спроможності в окремо взятій країні може бути вельми нестабільною.

Враховуючи перераховані особливості ризиків інвестиційного проєкту $\left(R_{\text {ип }}\right)$ - це система чинників, що виявляється у вигляді комплексу ризиків (загроз), індивідуальних для кожного учасника проєкту як в кількісному, так і в якісному відношенні. Систему ризиків можна представити в наступному вигляді

$$
\boldsymbol{R}_{u n}=\left|\begin{array}{cccc}
\boldsymbol{R}_{11} & \boldsymbol{R}_{12} & \ldots & \boldsymbol{R}_{1 n} \\
\ldots & \ldots & \ldots & \ldots \\
\ldots & \ldots & \ldots & \ldots \\
\boldsymbol{R}_{m 1} & \boldsymbol{R}_{m 2} & \ldots & \boldsymbol{R}_{m n}
\end{array}\right|,
$$

де $n$ - можлива кількість ризиків інвестиційного проєкту; $m$ кількість учасників проєкту.

Система факторів що утворює ризик інвестиційного проєкту є складною системою з численними взаємозв'язками, що виявляються для кожного з учасників проєкту у вигляді індивідуальної комбінації - комплексу, тобто ризик і-го учасника проєкту (Ri) описується формулою

$$
\boldsymbol{R}_{i}=\left\{\boldsymbol{R}_{i 1}, \boldsymbol{R}_{i 2}, \ldots \boldsymbol{R}_{i n}\right\} .
$$

Висновки. Отож, стовпець матриці (11) при цьому показує, що 
значення будь-якого ризику для кожного учасника проєкту виявляється також індивідуально. Проте $€$ загальна напрацьована поетапна послідовність дій аналізу ризиків.

Перший крок аналізу ризиків, як правило, починають 3 якісного аналізу, метою якого є ідентифікація ризиків. Ця мета розкладається на наступні задачі:

- виявлення всього спектру ризиків, властивих інвестиційному проєкту;

- опис ризиків;

- класифікація і угрупування ризиків;

- аналіз початкових допущень.

Другою фазою (кроком) аналізу ризиків є кількісна їх оцінка, метою якої є вимірювання ризику, що обумовлює рішення наступних задач:

- формалізації невизначеності;

- розрахунку ризиків;

- оцінки ризиків;

- обліку ризиків.

На третьому кроці аналізують ризики апріорні і теоретичні, думки трансформують в практичну діяльність управління ризиками. Це відбувається у момент закінчення проєктування стратегії менеджменту в умовах ризику і початок їі реалізації. Цей же етап завершує й інжиніринг інвестиційних проєктів.

Четвертий етап - це, по суті, контроль, який $€$ початком реінжинірингу інвестиційного проєкту і завершує процес ризикменеджменту, забезпечуючи йому циклічність процедур аналізу і підведення поетапного підсумку як бази управлінського рішення.

1. Бланк Й. А. Инвестиционный менеджмент. Киев : Ника-Центр, 2001. 2. Касаткина Е.В. Оценка эффективности инвестиционных проектов: методологические проблемы и направления их решения. Известия Российского государственного педагогического университета им. А.И. Герцена. 2010. № 126. С. 4251. 3. Высоцкая Т.Р. Метод реальных опционов в оценке стоимости инвестиционных проектов. Финансовый менеджмент. 2006 № 2. 4. Габович Б. А., ДангА. 3., Мищенко А. В. Стохастическая модель принятия инвестиционных решений в условиях риска. Финансовый менеджмент. 2009. № 2. 5. Крамаренко Г. 0., Чорна О. Є. Фінансовий менеджмент : підручник. 2-ге вид. Київ : Центр учбової літератури, 2009. 520 с. 7. Мамотенко Д. Ю. Оцінка ефективності інвестиційних проектів. Вісн. Нац. ун-ту «Львів. політехніка». 2008. № 628. С. 209-215. 8. Калугин В.А. Экспресс-оценка инвестиционного предложения. Финансовый менеджмент. 2006. № 3. 9. Крупка Я. Д., Литвин Б. М. Інвестиційний бізнес-план. К., 1997. 10. Савчук В. П., Прилипко С.И., Величко Е. Г. Анализ и разработка 
инвестиционных проектов. Киев, 2008. 11. Холт Р. Основы финансового менеджмента. Москва : «Дело Ltd», 2005. 12. Холт Р. Планирование инвестиций. Москва : «Дело Ltd», 2005. 13. Савчук В. П., Прилипко С. И., Величко Е. Г. Анализ и разработка инвестиционных проектов : учеб. пособ. Киев : Абсолют-В, Эльга, 2009. 14. Федоренко В. Г. Інвестиції і капітальне будівництво в ринкових умовах. Київ: Міжнар. фінанс. агенція, 2008. 15. Положення про Міжвідомчу комісію з питань дердавних інвестиційних проектів : Постанова КМУ від 22.07.2015. № 571. URL: https: // zakon.rada.gov.ua/laws/show/571-2015-\%D0\%BF\#Text (дата звернення: 15.09.2021).

\section{REFERENCES:}

1. Blank Y. A. Investitsionnyiy menedjment. Kiev : Nika-TSentr, 2001. 2. Kasatkina E. V. Otsenka effektivnosti investitsionnyih proektov: metodologicheskie problemyi i napravleniya ih resheniya. Izvestiya Rossiyskogo gosudarstvennogo pedagogicheskogo universiteta im. A.l. Gertsena. 2010. № 126. S. 42-51. 3. Vyisotskaya T. R. Metod realnyih optsionov $v$ otsenke stoimosti investitsionnyih proektov. Finansovyiy menedjment. 2006 № 2. 4. Gabovich B. A., Dang A. Z., Mischenko A. V. Stohasticheskaya model prinyatiya investitsionnyih resheniy $v$ usloviyah riska. Finansovyiy menedjment. 2009. № 2. 5. Kramarenko H. O., Chorna O. Ye. Finansovyi menedzhment : pidruchnyk. 2-he vyd. Kyiv : Tsentr uchbovoi literatury, 2009. 520 s. 7. Mamotenko D. Yu. Otsinka efektyvnosti investytsiinykh proektiv. Visn. Nats. un-tu «Lviv. politekhnika». 2008. № 628. S. 209-215. 8. Kalugin V. A. Ekspress-otsenka investitsionnogo predlojeniya. Finansovyiy menedjment. 2006. № 3. 9. Krupka Ya. D., Lytvyn B. M. Investytsiinyi biznes-plan. K., 1997. 10. Savchuk V. P., Prilipko S. I., Velichko E. G. Analiz i razrabotka investitsionnyih proektov. Kiev, 2008. 11. Holt R. Osnovyi finansovogo menedjmenta. Moskva : «Delo Ltd», 2005. 12. Holt R. Planirovanie investitsiy. Moskva : «Delo Ltd», 2005. 13. Savchuk V. P., Prilipko S. I., Velichko E. G. Analiz i razrabotka investitsionnyih proektov : ucheb. posob. Kiev : Absolyut-V, Elga, 2009. 15. Polozhennia pro Mizhvidomchu komisiiu z pytan derdavnykh investytsiinykh proektiv : Postanova KMU vid 22.07.2015. № 571. URL: https: // zakon.rada.gov.ua/laws/show/571-2015\%D0\%BF\#Text (data zvernennia: 15.09.2021).

Stasiuk B. B. [1; ORCID ID: 0000-0002-0859-5681], Senior Lecturer

${ }^{1}$ National University of Water and Environmental Engineering, Rivne

\section{JUSTIFICATION OF MANAGEMENT DECISIONS IN THE CHOICE OF INVESTMENT PROJECTS, FINANCIAL ASPECT}

The essence and significance of substantiation of investments in large social and ecological projects and problems of evaluation of the efficiency of such projects are revealed. Various investment projects financed from the budget of all levels are subject to the state examination, which is carried out 
by authorized public authorities. Investment projects, regardless of the sources of financing and forms of ownership of capital investment objects, are subject to examination before their approval, in particular, ecological examination. The decision to evaluate the investment project is to determine the different types of the effectiveness of the investment project: social, commercial efficiency of participation in the project. The effectiveness of participation in the project, in turn, includes efficiency for participating companies, efficiency for shareholders of participating companies, budget efficiency. In this case, "efficiency" means the extent to which the implementation of this project meets the purpose and interests of its participants, as well as those directly affected by the implementation process.

Therefore, it is necessary to select the criteria for evaluating investment projects, which will be the basis for management decisions. Substantiation of economic efficiency of the investment project is characterized by a system of indicators that reflect the ratio of costs and financial results of the project. Costs and other results of the project in the calculations of economic efficiency are expressed in the form of cash flow.

The main methods of investment project analysis and their essence, advantages, and disadvantages are analyzed in the article. To determine the price of risk, it is recommended to use indicators that take into account both the possibility of an adverse event and the amount of damage from it. Such indicators may be variance, standard deviation, and coefficient of variation. For the possibility of economic interpretation and comparative analysis of these indicators, it is recommended to translate them into the monetary format. The complex of investment project estimation with the aim of risks minimization is suggested.

Keywords: methods; management decisions; investment projects; efficiency; inflation risk; costs; cash flow; expertise; socio-ecological project; profitability; financial management.

Стасюк Б. Б. [1; ORCID ID: 0000-0002-0859-5681], старший преподаватель

${ }^{1}$ Национальный университет водного хозяйства и природопользования, г. Ровно

\section{ОБОСНОВАНИЕ УПРАВЛЕНЧЕСКИХ РЕШЕНИЙ ПРИ ВЫБОРЕ ИНВЕСТИЦИОННЫХ ПРОЕКТОВ, ФИНАНСОВЫЙ АСПЕКТ}

Раскрыты суть и значение обоснования инвестиций в крупные социально-экологические проекты и проблемы оценки эффективности таких проектов. Различные инвестиционные проекты, финансируемые за счет средств бюджета всех уровней подлежат государственной 
экспертизе, осуществляемой уполномоченными на то органами государственной власти. Инвестиционные проекты независимо от источников финансирования и форм собственности объектов капитальных вложений подлежат экспертизе к их утверждению, в частности, экологической экспертизе. Решение об оценке инвестиционного проекта состоит в определении различных видов эффективности инвестиционного проекта: общественной, коммерческой эффективности участия в проекте. Эффективность своей роли в проекте, в свою очередь, включает: эффективность для компаний-участников, эффективность для акционеров компаний-участников, бюджетную эффективность. При этом, под эффективностью подразумевается то, насколько реализация данного проекта отвечает целям и интересам его участников, а также тех, кого непосредственно касается процесс реализации.

Поэтому необходимо подобрать критерии оценки инвестиционных проектов, которые будут основой для принятия управленческих решений. Обоснование экономической эффективности инвестиционного проекта характеризуется системой показателей, отражающих соотношение затрат и финансовых результатов реализации проекта. Расходы и другие результаты проекта в расчетах экономической эффективности выражаются в виде денежного потока. Проанализированы основные методы оценки инвестиционных проектов их сущность, преимущества и недостатки. Для определения цены риска рекомендуется использовать показатели, которые учитывают как возможность наступления неблагоприятного события, так и величину ущерба от него. Такими показателями могут быть дисперсия, среднеквадратическое отклонение и коэффициент вариации. Для способности экономического толкования и сравнительного анализа этих характеристик рекомендуется переводить их в денежный формат. Предложен комплекс показателей для оценки инвестиционных проектов с минимизацией рисков.

Ключевые слова: методы; управленческие решения; инвестиционные проекты; эффективность; инфляционный риск; расходы; денежный поток; экспертиза; социально-экологический проект; рентабельность; финансовый менеджмент. 